\title{
Chitosan and Cystatin/Lysozyme Preparation as Protective Edible Films Components
}

\author{
Anna Zimoch-Korzycka, ${ }^{1}$ Antoine Rouilly, ${ }^{2,3}$ Lukasz Bobak, ${ }^{1}$ \\ Andrzej Jarmoluk, ${ }^{1}$ and Michał Korzycki ${ }^{1}$ \\ ${ }^{1}$ Department of Animal Products Technology and Quality Management, Faculty of Food Science, Wrocław University of Environmental \\ and Life Sciences, 37/41 Chelmonskiego Street, 51-630 Wrocław, Poland \\ ${ }^{2}$ INRA, UMR 1010 CAI, 31030 Toulouse, France \\ ${ }^{3}$ Université de Toulouse, INP-ENSIACET, Laboratoire de Chimie Agro-Industrielle (LCA), 31030 Toulouse, France
}

Correspondence should be addressed to Anna Zimoch-Korzycka; anna.zimoch@up.wroc.pl

Received 27 August 2015; Revised 8 October 2015; Accepted 11 October 2015

Academic Editor: Yulin Deng

Copyright ( 2015 Anna Zimoch-Korzycka et al. This is an open access article distributed under the Creative Commons Attribution License, which permits unrestricted use, distribution, and reproduction in any medium, provided the original work is properly cited.

\begin{abstract}
This work characterizes biological, physical, and chemical properties of films formed from an aqueous solution of hydroxypropyl methylcellulose (HPMC), with different concentrations of chitosan $(\mathrm{CH})$ and bioactive cystatin/lysozyme preparation $(\mathrm{C} / \mathrm{L})$. The properties of biocomposites were examined by Dynamic Mechanical Analysis (DMA), Fourier's transfer infrared spectroscopy (FTIR), water vapour permeability (WVP), and tensile testing. Antimicrobial activity against Micrococcus flavus, Bacillus cereus, Escherichia coli, Pseudomonas fluorescens, and Candida famata was conducted. Films glass transition and storage modulus were dependent on the $\mathrm{C} / \mathrm{L}$ and $\mathrm{CH}$ concentration. Modulus values decreased during the temperature scan and with higher reagents levels. An increase of $\mathrm{CH}$ and $\mathrm{C} / \mathrm{L}$ concentrations in the films resulted in a decrease in tensile strength from 2.62 to $1.08 \mathrm{MPa}$. It suggests the hydrolyzing influence of $\mathrm{C} / \mathrm{L}$, also observed in smaller peak size of $\alpha$ relaxation. $\mathrm{C} / \mathrm{L}$ addition caused shifting $T_{g}$ to higher temperature. DMA and FTIR analysis proved that HPMC and $\mathrm{CH}$ are compatible polymers. Water resistance was improved with rising $\mathrm{CH}$ concentration from $1.08 E-09$ to $7.71 E-10 \mathrm{~g} / \mathrm{m} * \mathrm{~s} * \mathrm{~Pa}$. The highest inhibition zone in $M$. flavus and C. famata was recorded at the highest concentration of $\mathrm{CH}$ and $\mathrm{C} / \mathrm{L}$.
\end{abstract}

\section{Introduction}

The growing interest and demand of producers as well as consumers for environmental friendly, biodegradable, biocompatible, and bioactive materials to produce edible films and coatings are observed. Most polymers and bioactive substances have very good film forming properties. These include polysaccharides: chitosan [1], cellulose [2], starch [3], and carrageenan [4], proteins: gelatin [5], collagen [6], and lipids [7]. Enzymes are also used to improve or change features of polymers: transglutaminase [8], lysozyme [9], or cellulase [10].

Derivatives of cellulose are composed of the same $\beta$-(1 $\rightarrow$ 4)-glycosidic units with different substituents methyl, hydroxypropyl, or carboxyl. Hydroxypropyl methylcellulose is cellulose ether with hydrophilic groups, hydroxyl groups, which provide good interaction of HPMC with water [11]. The mechanical and thermal properties of HPMC are influenced by presence of these groups and water uptake [12]. HPMC exhibits thermogelation and has excellent filmmaking properties, high solubility, efficient oxygen, and lipid barrier properties $[13,14]$.

Chitosan is a biopolymer, which has a $\beta$ - $(1 \rightarrow 4)$-Dglucopyranose backbone similar to cellulose. The difference is that chitosan possesses acetamide group instead of the hydroxyl group in $\mathrm{C} 2$ position of glucose residue. The similarity of primary structure of both polymers suggests possibility of formation of homogenous edible films based on chitosan and cellulose derivatives [15]. The modification of chitosan with different polysaccharides or proteins may be an effective way to improve mechanical properties of chitosan for which antimicrobial [16] and oxygen barrier properties were reported [17].

Interactions of the polymers with bioactive substances have been recently studied extensively [18-20]. Egg white is 
rich natural source of bioactive proteins such as lysozyme, ovotransferrin, avidin, ovoflavoprotein, and proteinase inhibitors (ovoinhibitor, ovomucoid, ovostatin, and cystatin). Classical separation methods of proteins are based on the salting out of solution or precipitation with alcohol. These techniques have been extended by the ion exchange chromatography and membrane separation in recent years. Nowadays, researchers are looking for separation methods, which will be cheap, easy, nontoxic, and maintaining the highest biological activity of isolated proteins. They are important factors in commercial production and in food and pharmaceutical applications in view of their health activities [21]. The lysozyme damages cell walls, especially Grampositive bacteria by catalyzing hydrolysis of $\beta-(1 \rightarrow 4)$ linkages between particles of $\mathrm{N}$-acetylmuramic acid and L-glucosamine [22]. The cystatin is a protein inhibitor of cysteine proteinases [23] and has very high antimicrobial $[24,25]$ and antiviral properties [26]. A special challenge is to develop a cheap method of cystatin isolation, because cystatin is present in small amount (around 0.05\%) in egg white. Skiba et al. have proposed a thermochemical method of initial isolation of bioactive proteins of egg white, especially cystatin [27]. They used diversity of chemo- and thermoresistance property of egg proteins for their separation. Lysozyme, cystatin, and ovomucoid are acid soluble and thermally stable, even when heated up to $100^{\circ} \mathrm{C}$. The rest of the egg white proteins (ovotransferrin, ovalbumin) in such conditions will coagulate. The production process of bioactive preparation can be carried out in processing plants, but the obtained mixture could be used just for foodstuff. Extension of application in pharmaceutical usage is possible after purification by chromatography methods. Possibility to obtain cystatin/lysozyme preparation with ovomucoid was proved [27] and bioactivity of these single proteins was confirmed by researchers [28].

Applicable opportunities of bioactive preparation in HPMC biocomposites were assessed, in view of the aim of this study, which was to develop HPMC films with addition of cystatin/lysozyme preparation and chitosan as well as evaluate their antimicrobial activity and thermomechanical, barrier, and chemical changes.

\section{Materials and Methods}

2.1. Materials. The materials included HPMC (Walocel HM 100 PA 2208 FG, Wolff Cellulosics), chitosan (low molecular weight, DD $75-85 \%, \mathrm{Mw}=150 \times 10^{-3}$, low viscosity ranged between 20 and 200 cps, Aldrich), DL-lactic acid (85\%, Sigma), and glycerol 99\% (Aldrich).

2.2. Cystatin/Lysozyme Isolation. A substrate of C/L preparation was homogenous hen egg white, which was diluted with an equal $0.25 \% \mathrm{NaCl}$ following the procedure described by Skiba et al. [27]. The solution was brought to $\mathrm{pH} 3.0$ with $1 \mathrm{~N}$ $\mathrm{HCl}$ and heated to $60^{\circ} \mathrm{C}$ for 30 minutes. Protein suspension was obtained and centrifuged at $9300 \times \mathrm{g}$ for 20 minutes to precipitate ovomucin and other eggs' protein. Supernatant containing bioactive substances was frozen at $-40^{\circ} \mathrm{C}$, then lyophilized, and stored at $4^{\circ} \mathrm{C}$.
2.3. Activities of Cystatin and Lysozyme. Activity of cystatin against papain was analyzed according to colorimetric method reported by Siewiński [29], where BANA (hydrochloride Na-benzoyl-DL-arginyl-B-naftylamid) was a substrate of hydrolysis and reaction was stopped by the addition of DMBA ( $p$-dimethylaminobenzaldehyde). Absorbance was measured at $\lambda=450 \mathrm{~nm}$. One unit of inhibitory activity of cystatin equals one unit of papain activity, which is quantity of enzyme able to hydrolyze $1.0 \mathrm{mM}$ of substrate in one minute (standard conditions, $37^{\circ} \mathrm{C}$ ).

Lysozyme activity was analyzed by spectrophotometrical method [30]. Bacterial cells of Micrococcus lysodeikticus were used as a substrate for lysozyme. The dynamic turbidity changes were reported by measuring of absorbance at $\lambda=$ $450 \mathrm{~nm}$ in $25^{\circ} \mathrm{C}$, every 60 seconds during 6 minutes.

2.4. Film Preparation. HPMC was dissolved in bidistilled heated $\left(70^{\circ} \mathrm{C}\right)$ water for preparation of solution. Chitosan was solubilized in $2 \%(\mathrm{v} / \mathrm{v})$ aqueous lactic acid solution in room temperature. Both solutions were stirred with $400 \mathrm{rpm}$ for 12 hours. C/L stock solution was prepared by dissolving $20 \% \mathrm{C} / \mathrm{L}$ preparation in bidistilled water followed by centrifugation $(9300 \times \mathrm{g})$ and filtration to remove insoluble residues. The same procedure was applied to prepare protein solution. Glycerol was used as plasticizer in amount of $25 \%$ of polymers dry mass. Thus prepared solutions of hydrocolloids, preparation of $\mathrm{C} / \mathrm{L}$, equivalent of proteins, and glycerol were mixed in suitable proportions to obtain final concentrations of the components shown in Table 1. The HPMC and $\mathrm{CH}$ solutions at three different levels, $0 \%, 1 \%$, and $2 \%$, were blended with $25 \% \mathrm{wt} / \mathrm{wt}$ of glycerol (of dry weight of the used polymers) and $\mathrm{C} / \mathrm{L}$ mixture (at three different levels: $0 \%, 0.5 \%$, and $1 \%$, which correspond to $0 / 0,0.35 / 96$, and $0.7 / 192 \mathrm{U} / \mathrm{g}$ activity of $\mathrm{C} / \mathrm{L}$, resp.) in different ratio (wt/wt). All experimental samples were centrifuged at $8400 \times \mathrm{g}$ for 20 minutes to remove air bubbles. Twelve $\mathrm{mL}$ of film forming solutions was then cast on leveled, coated by Teflon glass plate on an area of $66 \times$ $77 \mathrm{~mm}$, and dried at $25^{\circ} \mathrm{C}$ and $60 \% \mathrm{RH}$ for 48 hours. The dried biocomposites were peeled from plates and cut into pieces for the measurements of thermal and mechanical properties.

2.5. Dynamic Mechanical Analysis. Strips of HPMC films (5 mm length and $7 \mathrm{~mm}$ width) were subjected to Dynamic Mechanical Analysis using TRITEC 2000 DMA from Triton Technology. Samples were heated from $-80^{\circ} \mathrm{C}$ to $70^{\circ} \mathrm{C}$ at a heating rate of $2^{\circ} \mathrm{C} / \mathrm{min}$ and frequency of $1 \mathrm{~Hz}$. $E^{\prime}$, storage modulus, and $\tan \delta$, loss factor, were recorded.

2.6. Tensile Test. Tensile test was performed in a universal testing machine HSKT (Tinius Olsen). The samples were cut into $12 \mathrm{~mm} \times 65 \mathrm{~mm}$ dumbbell-shaped test specimen with contraction of the following dimensions: $7 \mathrm{~mm} \times 15 \mathrm{~mm}$. The film strips were uniaxially stretched immediately after removing from the chamber $\left(25^{\circ} \mathrm{C}, 60 \% \mathrm{RH}\right)$ to minimize moisture content variability. Tensile strength (TS, Pa) values were obtained from equation of measured maximum force (N) divided by film cross-section (thickness $\times$ width) and elongation at break (EL, percent at break point) values were 
TABLE 1: Experimental design of film forming hydrosols.

\begin{tabular}{|c|c|c|c|c|c|}
\hline \multirow{2}{*}{ Variants } & \multicolumn{2}{|c|}{ Variability factors } & \multicolumn{3}{|c|}{ Constant factors } \\
\hline & Chitosan [\%] & Cystatin/lysozyme [\%] & HPMC [\%] & Glycerol [\%] & Lactic acid [\%] \\
\hline $\mathrm{CH} 0 \mathrm{C} / \mathrm{LO}$ & & 0 & & & \\
\hline $\mathrm{CH} 0 \mathrm{C} / \mathrm{L} 0.5$ & 0 & 0.5 & & & \\
\hline $\mathrm{CH} 0 \mathrm{C} / \mathrm{L} 1$ & & 1 & & & \\
\hline CH1C/L0 & & 0 & & & \\
\hline CH1C/L0.5 & 1 & 0.5 & 0.5 & 25 (of dry weight of used polymers) & 1 \\
\hline $\mathrm{CH} 1 \mathrm{C} / \mathrm{L} 1$ & & 1 & & & \\
\hline $\mathrm{CH} 2 \mathrm{C} / \mathrm{L} 0$ & & 0 & & & \\
\hline $\mathrm{CH} 2 \mathrm{C} / \mathrm{L} 0.5$ & 2 & 0.5 & & & \\
\hline $\mathrm{CH} 2 \mathrm{C} / \mathrm{L} 1$ & & 1 & & & \\
\hline
\end{tabular}

reported as deformation at break divided by the initial length and multiplying by 100 .

2.7. Fourier Transform Infrared Spectrometry. Infrared spectra were registered in FTIR-460 Plus, Specac spectrometer. The transmission spectra were collected at $4 \mathrm{~cm}^{-1}$ resolution and by 32 scans, directly on films with a golden bridge reflection apparatus. The reference background was air.

2.8. Water Vapour Permeability. Water vapour permeability of the film was determined following ASTM E-96 method [31]. The cups were filled with $100 \mathrm{~cm}^{3}$ of distilled water each. A sample was placed in between the cup and the ring cover of each cup. Then, they were stored at $4^{\circ} \mathrm{C}$ and $60 \% \mathrm{RH}$. Cups were weighed every hour for $6 \mathrm{~h}$. Water vapour transmission rate (WVTP) was estimated using the following equation:

$$
\text { WVTR }=\frac{G}{(t \times A)},
$$

where $G$ is the change in weight (g), $t$ is the time (h), and $A$ is the test area $\left(\mathrm{m}^{2}\right)$.

Water vapour permeability (WVP) was calculated as

$$
\mathrm{WVP}=\frac{(\mathrm{WVTR} \times T)}{\Delta P},
$$

where $T$ is the thickness of the test specimen $(\mathrm{mm})$ and $\Delta P$ is the partial pressure difference of the water vapour across the film.

2.9. Antimicrobial Activity. Disc diffusion test was used to determine the antibacterial activity of biocomposites. $B$. cereus B3p, M. flavus ATCC10240, P. fluorescens PCM 1994, E. coli PCM 2560, and C. famata MIla were selected for determination. Gram-positive and Gram-negative bacteriainoculums were prepared by growing cells in enriched broth for $24 \mathrm{~h}$ at $37^{\circ} \mathrm{C}$. Yeast was inoculated in YM broth for $24 \mathrm{~h}$ at $30^{\circ} \mathrm{C}$. Optical density of the bacterial culture was measured in a Ray Leigh UV 1800 spectrophotometer at $\lambda=550 \mathrm{~nm}$. The inoculum containing $10^{6} \mathrm{CFU} / \mathrm{mL}$ was evenly spread on agar plates. The uniform discs with $20 \mathrm{~mm}$ diameter of appropriate films were sterilized by UV for 2 minutes and placed on the surface of the agar plates. The plates were incubated at $37^{\circ} \mathrm{C}$ for bacteria and at $30^{\circ} \mathrm{C}$ for yeast for $24 \mathrm{~h}$. The diameter of the inhibition zone ( $\mathrm{mm}$ ) was measured using the GIMP 2 program.

2.10. Statistical Analysis. Data were analyzed by analysis of variance (ANOVA). The differences between means were established with Duncan Test. Statistical analyses were performed using the Software STATISTICA (Version 7.1, Statsoft, Inc.). Significance of differences was defined at $p \leq 0.05$. All experiments were performed in triplicate.

\section{Results and Discussion}

3.1. Tensile Test. The main and interaction effects of $\mathrm{CH}$ and $\mathrm{C} / \mathrm{L}$ blend on tensile properties of HPMC films are showed in Table 2. There was significant impact of chitosan, C/L preparation, and interaction of blended factors on tensile strength (TS) and elongation at break (EB). TS of the films significantly increased $(p<0.05)$ from $1.80,3.61$ to $4.72 \mathrm{MPa}$ with the addition of 0,1 , and $2 \%$ of chitosan, respectively. On the contrary, it decreased with the $0,0.5$, and $1 \%$ addition of cystatin/lysozyme preparation, from $6.51,2.89$ to $0.72 \mathrm{MPa}$. Chitosan films with protein addition provide much more tensile resistance than without it [32]. Lysozyme and cystatin are both proteins, but the brittleness was caused by the presence of lysozyme. Lysozyme is an enzyme with degraded properties towards $\beta$ - $(1 \rightarrow 4)$ linkages of polysaccharides and could hydrolyze both chitosan and hydroxypropyl methylcellulose [33]. Simultaneously, implicated in our study, chitosan with high deacetylation degree is less susceptible to enzymatic degradation [34] but cannot be stopped completely and the products, oligomers, can still have intermediate viscosities [18]. On the other hand, the reason of weaker structure and integrity of films could be caused by disruption of crystalline structure formation during drying and weakening intermolecular hydrogen bonds of chitosan and HPMC [34]. Existence of seven and six homogenous groups in interactional effects was showed and proved high complicity of $\mathrm{CH}$ and $\mathrm{C} / \mathrm{L}$ impact on TS and $\mathrm{EB}$, respectively. The elongation at break was enlarged with chitosan $2 \%$ (60.42\%), compared to its 0 and $1 \%$ addition (50.89 and 
TABLE 2: Mechanical properties of films.

\begin{tabular}{|c|c|c|c|c|c|}
\hline \multicolumn{4}{|c|}{ Main effects } & \multicolumn{2}{|c|}{ Interaction effects } \\
\hline $\mathrm{CH}[\%]$ & TS [MPa] & $\mathrm{C} / \mathrm{L}[\%]$ & TS [MPa] & $\mathrm{CH} \times \mathrm{C} / \mathrm{L}$ & TS [MPa] \\
\hline \multirow{3}{*}{0} & \multirow{3}{*}{$1.80 \pm 0.29^{\mathrm{a}}$} & \multirow{3}{*}{0} & \multirow{3}{*}{$6.51 \pm 1.07^{\mathrm{a}}$} & $0 \times 0$ & $2.62 \pm 0.23^{\mathrm{cd}}$ \\
\hline & & & & $0 \times 0.5$ & $2.06 \pm 0.05^{c}$ \\
\hline & & & & $0 \times 0.1$ & $0.72 \pm 0.01^{\mathrm{ab}}$ \\
\hline \multirow{3}{*}{1} & \multirow{3}{*}{$3.61 \pm 0.98^{\mathrm{b}}$} & \multirow{3}{*}{0.5} & \multirow{3}{*}{$2.89 \pm 0.22^{\mathrm{b}}$} & $1 \times 0$ & $7.09 \pm 0.36^{\mathrm{f}}$ \\
\hline & & & & $1 \times 0.5$ & $3.36 \pm 0.13^{\mathrm{e}}$ \\
\hline & & & & $1 \times 1$ & $0.37 \pm 0.03^{\mathrm{a}}$ \\
\hline \multirow{3}{*}{2} & \multirow{3}{*}{$4.72 \pm 1.32^{\mathrm{c}}$} & \multirow{3}{*}{1} & \multirow{3}{*}{$0.72 \pm 0.10^{c}$} & $2 \times 0$ & $9.83 \pm 0.45^{\mathrm{g}}$ \\
\hline & & & & $2 \times 0.5$ & $3.25 \pm 0.16^{\mathrm{de}}$ \\
\hline & & & & $2 \times 1$ & $1.08 \pm 0.05^{\mathrm{b}}$ \\
\hline $\mathrm{CH}[\%]$ & EB [\%] & $\mathrm{C} / \mathrm{L}[\%]$ & EB [\%] & $\mathrm{CH} \times \mathrm{C} / \mathrm{L}$ & EB [\%] \\
\hline \multirow{3}{*}{0} & \multirow{3}{*}{$50.89 \pm 5.46^{\mathrm{b}}$} & \multirow{3}{*}{0} & \multirow{3}{*}{$51.02 \pm 8.19^{\mathrm{b}}$} & $0 \times 0$ & $29.23 \pm 0.59^{\mathrm{e}}$ \\
\hline & & & & $0 \times 0.5$ & $59.50 \pm 0.55^{\mathrm{ab}}$ \\
\hline & & & & $0 \times 0.1$ & $63.93 \pm 0.88^{\mathrm{b}}$ \\
\hline \multirow{3}{*}{1} & \multirow{3}{*}{$36.27 \pm 7.80^{a}$} & \multirow{3}{*}{0.5} & \multirow{3}{*}{$58.92 \pm 1.06^{\mathrm{a}}$} & $1 \times 0$ & $40.90 \pm 1.27^{\mathrm{c}}$ \\
\hline & & & & $1 \times 0.5$ & $60.55 \pm 2.43^{\mathrm{ab}}$ \\
\hline & & & & $1 \times 1$ & $7.36 \pm 0.55^{\mathrm{d}}$ \\
\hline \multirow{3}{*}{2} & \multirow{3}{*}{$60.43 \pm 6.15^{\mathrm{c}}$} & \multirow{3}{*}{1} & \multirow{3}{*}{$37.64 \pm 8.27^{\mathrm{c}}$} & $2 \times 0$ & $82.93 \pm 2.34^{\mathrm{f}}$ \\
\hline & & & & $2 \times 0.5$ & $56.71 \pm 1.82^{\mathrm{a}}$ \\
\hline & & & & $2 \times 1$ & $41.63 \pm 2.82^{\mathrm{c}}$ \\
\hline $\mathrm{CH}[\%]$ & $\mathrm{WVP}[\mathrm{g} / \mathrm{m} * \mathrm{~s} * \mathrm{~Pa}]$ & $\mathrm{C} / \mathrm{L}[\%]$ & $\mathrm{WVP}[\mathrm{g} / \mathrm{m} * \mathrm{~s} * \mathrm{~Pa}]$ & $\mathrm{CH} \times \mathrm{C} / \mathrm{L}$ & $\mathrm{WVP}[\mathrm{g} / \mathrm{m} * \mathrm{~s} * \mathrm{~Pa}]$ \\
\hline \multirow{4}{*}{0} & \multirow{3}{*}{$1.08 \pm 0.03 E-09^{\mathrm{a}}$} & \multirow{3}{*}{0} & \multirow{3}{*}{$9.25 \pm 0.85 E-10^{\mathrm{a}}$} & $0 \times 0$ & $1.08 \pm 0.03 E-09^{\mathrm{a}}$ \\
\hline & & & & $0 \times 0.5$ & $1.12 \pm 0.11 E-09^{\mathrm{a}}$ \\
\hline & & & & $0 \times 1$ & $1.05 \pm 0.02 E-09^{\mathrm{a}}$ \\
\hline & & & & $1 \times 0$ & $1.06 \pm 0.02 E-09^{\mathrm{a}}$ \\
\hline \multirow[t]{3}{*}{1} & $9.71 \pm 0.61 E-10^{\mathrm{a}}$ & 0.5 & $1.02 \pm 0.08 E-09^{\mathrm{a}}$ & $1 \times 0.5$ & $1.02 \pm 0.17 E-09^{\mathrm{a}}$ \\
\hline & & & & $1 \times 1$ & $8.40 \pm 0.50 E-10^{\mathrm{ab}}$ \\
\hline & & & & $2 \times 0$ & $6.40 \pm 1.60 E-10^{\mathrm{b}}$ \\
\hline 2 & $7.71 \pm 0.87 E-10^{\mathrm{b}}$ & 1 & $8.78 \pm 0.53 E-10^{\mathrm{a}}$ & $2 \times 0.5$ & $9.30 \pm 2.00 E-10^{\mathrm{ab}}$ \\
\hline & & & & $2 \times 1$ & $7.40 \pm 0.70 E-10^{\mathrm{ab}}$ \\
\hline
\end{tabular}

Values with different letters $(\mathrm{a}-\mathrm{g})$ within the same column differ significantly $(p<0.05)$.

$36.27 \%$, resp.). EB decreased with $1 \%$ addition of $\mathrm{C} / \mathrm{L}$ preparation. The highest $\mathrm{TS}$ and $\mathrm{EB}$ were registered for samples with the highest amount of $\mathrm{CH}$. Hosseini et al. have reported 12.2 MPa tensile strength of film with $2 \%$ chitosan and $0.5 \%$ of glycerol [35]. However, 6\% of HPMC film with no plasticizer was registered at $63 \mathrm{MPa}$ [36], which is very high value because of the HPMC concentration and lack of glycerol. The same authors noted that with the increased concentration of plasticizer the TS decrease significantly. Worse resistance of our films is caused by addition of plasticizer and hydrophilic compounds, which create lower density of films and help in polymers chains movements. On the other hand, chitosan films made with lactic acid exhibit lower tensile strength and higher elongation than those made with acetic acid, which was registered by Kumar et al. [37].

3.2. Dynamic Mechanical Analysis. Glass transition $T_{g}$ identifiers of DMA test are large drop in storage modulus $E^{\prime}$ and a peak in $\tan \delta$ (Figures 1(a), 1(b), 1(c), 2(a), 2(b), and 2(c)).
Storage modulus is an index of rigidity of polysaccharides [38]. The location of the glass transition was shifted to the higher temperature with addition of $\mathrm{CH}$ and C/L. The $E^{\prime}$ curves increased from $120 \mathrm{MPa}$ for $\mathrm{CH} 0 \mathrm{C} / \mathrm{L} 0$ to $600 \mathrm{MPa}$ for $\mathrm{CH} 0 \mathrm{C} / \mathrm{L} 1$ and to $450 \mathrm{MPa}$ for $\mathrm{CH} 2 \mathrm{C} / \mathrm{L} 1$ films. One drop in $E^{\prime}$ was observed in DMA curves of polysaccharides films at $-40-5^{\circ} \mathrm{C}$. Wu et al. have presented study on cellulosechitosan blend and chitosan; the curves of storage modulus of chitosan showed a drop at $0-30^{\circ} \mathrm{C}$ [15]. The authors suggested that drop is related with hydration of side groups $\left(-\mathrm{CH}_{2} \mathrm{OH}\right)$ on chitosan. On the other hand, $\tan \delta$ curves showed two peaks; the first of them is characterized as the $\beta$ relaxation attributed to local mode in amorphous phase, and another one is designed as the $\alpha$ relaxation assigned to glass transition of amorphous phase [39]. $\operatorname{Tan} \delta$ is a measure of polysaccharide viscoelasticity. Wetton has also suggested that $\tan \delta$ peak size is correlated with the polymer in the composition of sample [40]. The $\alpha$ relaxation peaks were reduced after $\mathrm{C} / \mathrm{L}$ addition, which confirms degradative effect of lysozyme on main chain of polymers. The viscoelastic 


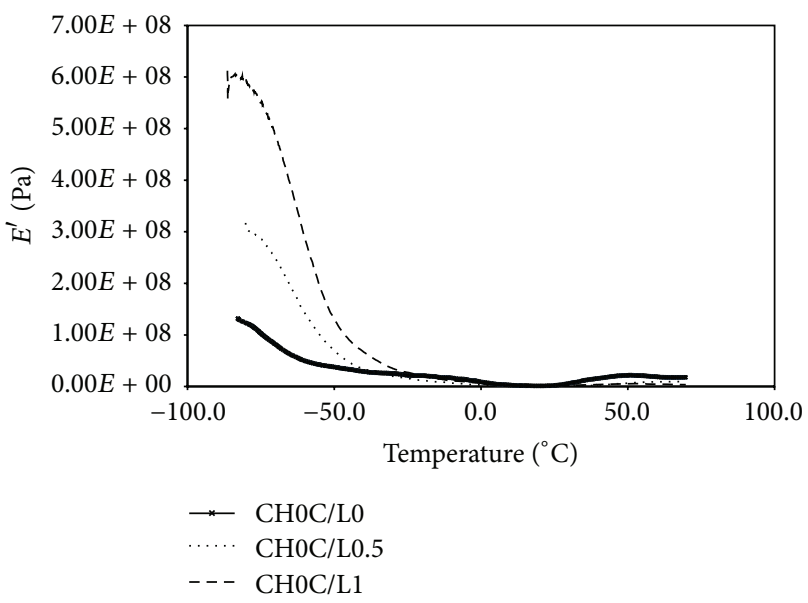

(a)

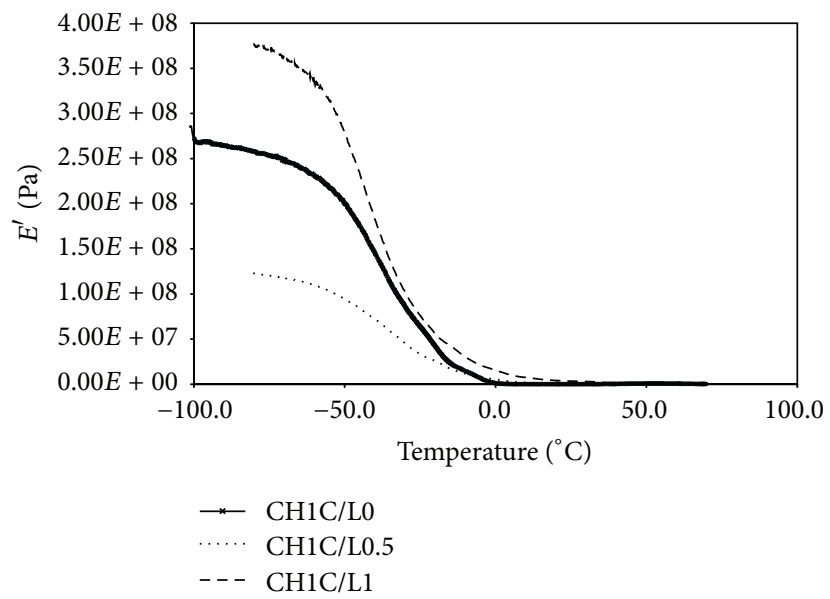

(b)

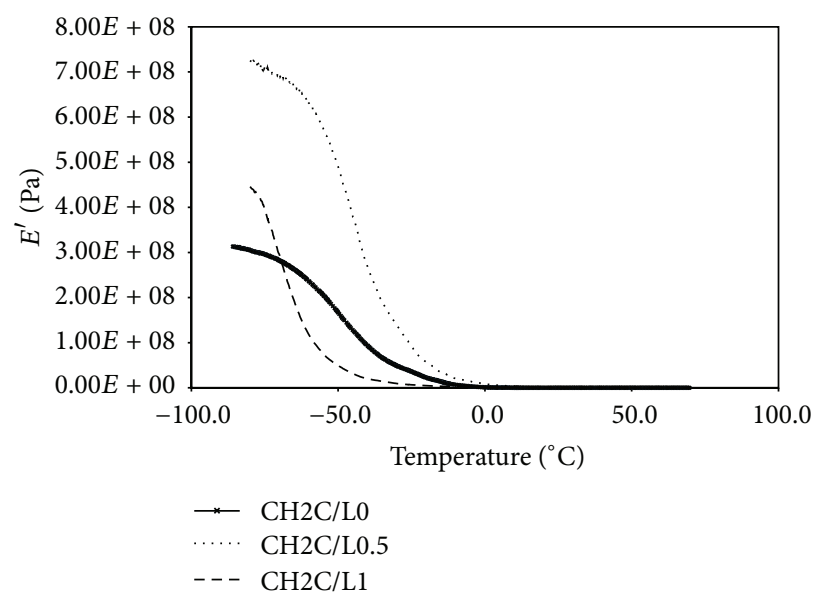

(c)

Figure 1: Storage modulus $\left(E^{\prime}\right)$ of HMPC, $\mathrm{CH}$, and C/L preparation films of (a) CH0C/L0, CH0C/L0.5, and CH0C/L1; (b) CH1C/L0, $\mathrm{CH} 1 \mathrm{C} / \mathrm{L} 0.5$, and $\mathrm{CH} 1 \mathrm{C} / \mathrm{L} 1$; and (c) $\mathrm{CH} 2 \mathrm{C} / \mathrm{L} 0, \mathrm{CH} 2 \mathrm{C} / \mathrm{L} 0.5$, and $\mathrm{CH} 2 \mathrm{C} / \mathrm{L} 1$ variants.

behavior of films was confirmed by loss factor values, which were between 0.1 and 0.9 . The $\mathrm{CH} 0 \mathrm{C} / \mathrm{L} 0$ film represented $\beta$ relaxation around $-80-(-50)^{\circ} \mathrm{C}$ and $T_{g}$ at $5-50^{\circ} \mathrm{C}$ samples with $\mathrm{CH}$ and $\mathrm{C} / \mathrm{L}$ were characterized by $\tan \delta$ peaks at $0^{\circ} \mathrm{C}$ and between 40 and $60^{\circ} \mathrm{C}$. The shift of $\beta$ and $\alpha$ transition temperature is the result of $\mathrm{CH}$ addition. Addition of chitosan has changed $T_{g}$ of HPMC to higher temperature but has not changed the width and height of the peak, which suggest that both polymers were mixing well. If the peak got broadness and dumping decrease, it will mean that polysaccharides are incompatible and semicompatible [41].

3.3. Fourier Transform Infrared Spectrometry. FTIR spectra of HPMC films had absorption bands at $3373.85 \mathrm{~cm}^{-1}$, $2885.95 \mathrm{~cm}^{-1}, 1649.80 \mathrm{~cm}^{-1}$, and $1041.37 \mathrm{~cm}^{-1}$ assigned to O$\mathrm{H}$ stretch, combination of methyl groups and $\mathrm{C}-\mathrm{H}$ stretch, $\mathrm{C}=\mathrm{O}$, and ether $\mathrm{C}-\mathrm{O}-\mathrm{C}$ stretch, respectively (Figure 3(a)). The position of the peaks of HPMC film spectrum is similar to those described by Gustafsson et al. [42]. Hydrogen bonding or other interactions between chemical groups on dissimilar polymers should theoretically cause a shift in peak position of the participating groups [43]. This kind of behavior was observed for the $\mathrm{OH}$ stretching since this peak shifted from $3373.85 \mathrm{~cm}^{-1}$ for HPMC film toward $3293.82 \mathrm{~cm}^{-1}$ for HPMC-CH mixtures (Figures 3(b) and 3(c)). Also increased $\mathrm{C} / \mathrm{L}$ preparation concentration changed position of the $\mathrm{OH}$ group from $3373.85 \mathrm{~cm}^{-1}$ for pure HPMC to $3350.71 \mathrm{~cm}^{-1}$ for HPMC-0.5\% C/L and to $3331.43 \mathrm{~cm}^{-1}$ for $\mathrm{HPMC}-1 \% \mathrm{C} / \mathrm{L}$ blends. According to Wu et al. [16], FTIR spectra of $\mathrm{CH}$ films had absorption bands at $3400-3480 \mathrm{~cm}^{-1}$ that responded to $\mathrm{OH}-3$ and $\mathrm{CH}_{2} \mathrm{OH}$ intra- and intermolecular hydrogen bonds, $1650 \mathrm{~cm}^{-1}$ for amide I, and $1557 \mathrm{~cm}^{-1}$ for amide II vibrational mode (Figures 3(b) and 3(c)).

3.4. Water Vapour Permeability. The results of statistical analysis of water vapour permeability are presented in Table 2. No significant effect of C/L preparation on water permeability was noted. Lopes, Martins, Fonseca, and Vicente (2011) also noticed that WVP of chitosan films were not affected by the enzyme, glucose oxidase incorporation [44]. Cellulase did not change water resistance of chitosan-hydroxypropyl 


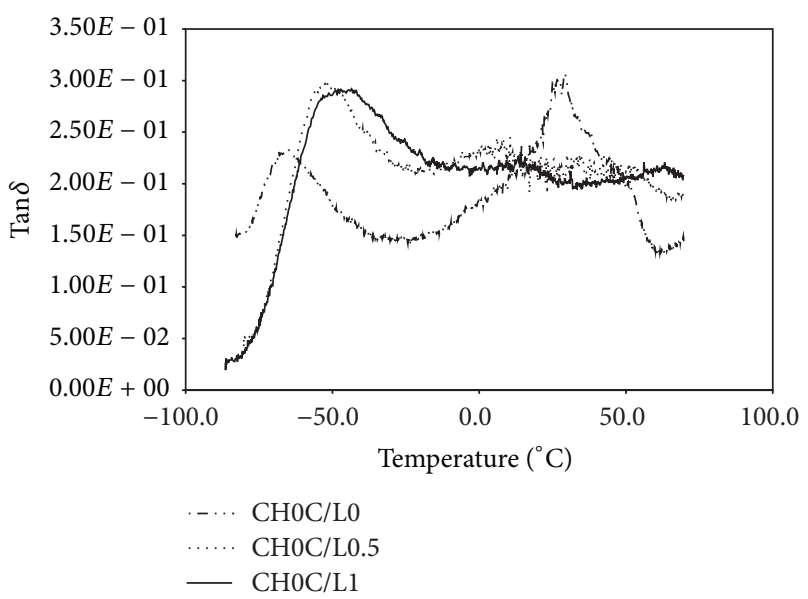

(a)

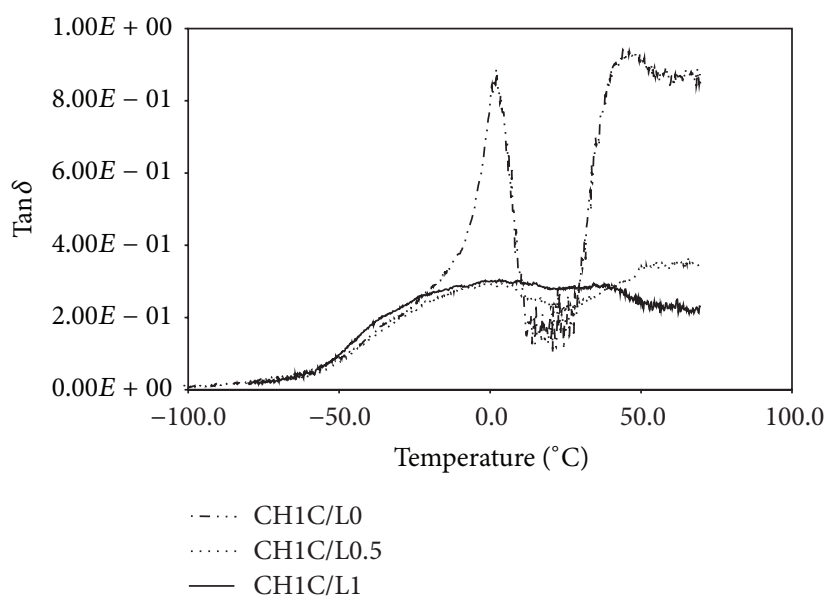

(b)

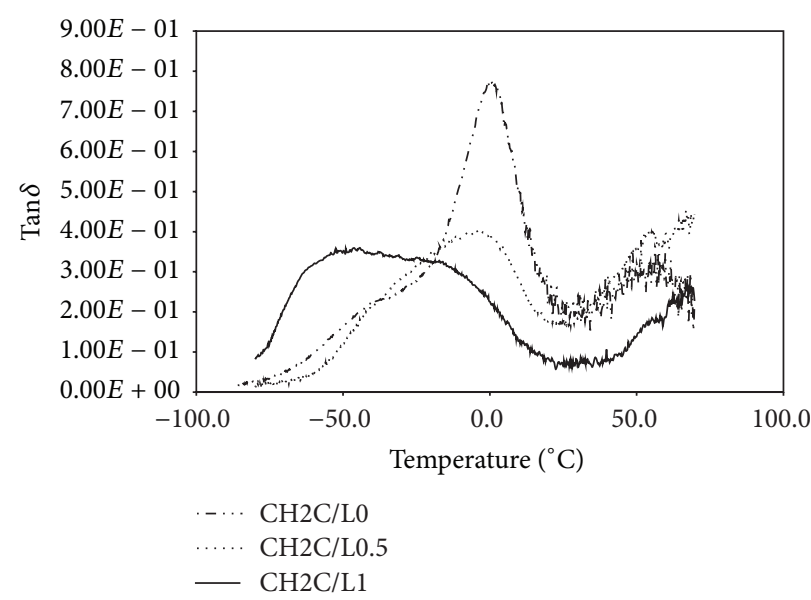

(c)

Figure 2: Tan $\delta$ of HPMC, CH, and C/L preparation films of (a) CH0C/L0, CH0C/L0.5, and CH0C/L1; (b) CH1C/L0, CH1C/L0.5, and $\mathrm{CH} 1 \mathrm{C} / \mathrm{L} 1$; and (c) $\mathrm{CH} 2 \mathrm{C} / \mathrm{L} 0, \mathrm{CH} 2 \mathrm{C} / \mathrm{L} 0.5$, and $\mathrm{CH} 2 \mathrm{C} / \mathrm{L} 1$ variants.

methylcellulose films [10]. However, interactional effect of $\mathrm{C} / \mathrm{L}$ and $\mathrm{CH}$ blend as well as chitosan influence was significant. Water resistance of tested films was higher with increasing concentration of chitosan from $1.08 E-09$ to $7.71 E-10 \mathrm{~g} / \mathrm{m} * \mathrm{~s} * \mathrm{~Pa}$ for 0 and $2 \%$ dose, respectively. Those results were confirmed by significant impact of simultaneous action of $\mathrm{CH}$ and $\mathrm{C} / \mathrm{L}$. The lowest WVP of $6.40 E-10 \mathrm{~g} / \mathrm{m} * \mathrm{~s} *$ $\mathrm{Pa}$ was noticed for film with the highest addition of chitosan and lack of lysozyme/cystatin preparation.

3.5. Antibacterial Activity. Antimicrobial effect of chitosan and cystatin/lysozyme preparation incorporated into the filmogenic hydrosol composition against $M$. flavus, B. cereus, E. coli, P. fluorescens, and C. famata was presented in Tables 3 and 4. Incorporation of $\mathrm{C} / \mathrm{L}$ and $\mathrm{CH}$ exhibited a clear inhibitory zone by the absence of bacterial and yeast growth. $\mathrm{CH}$ showed maximum inhibition of $33.0 \mathrm{~mm}$ against Grampositive bacteria, M. flavus, in the highest concentration of $2 \%$. These bacteria were selected for our test because of their high susceptibility to the various antimicrobial agents. Similar inhibiting effect of 32.8 against the same bacteria was observed with $1 \%$ addition of C/L. The highest concentration of $\mathrm{C} / \mathrm{L}$ statistically influenced inhibition of yeast growth $(29.6 \mathrm{~mm})$. Kolaczkowska et al. have proved antifungal activity of cystatin, affinity-purified from chicken egg white, against the most frequent human fungal pathogens of the genus Candida [25]. The mechanism of fungal growth inhibition by cystatin is not related to its protease inhibitory properties as Wesierska et al. suggested in their study regarding antibacterial activity of cystatin [24]. The purified recombinant proteins of tarocystatin from Colocasia esculenta such as $\mathrm{N}$-terminus peptide have a greater antifungal activity than full-length peptide. In addition, C-terminus peptide has not showed antifungal effect, which is proof of lack of connection to the inhibitory activity [45]. Significant reduction of two Gram-negative bacteria by every tested concentration of $\mathrm{CH}$ and $\mathrm{C} / \mathrm{L}$ was also noted. Characteristic intensification of antibacterial activity is also possible by the addition of hydrolytic enzymes, such as lysozyme to the chitosans films, which increases the inhibiting effect on Escherichia coli growth [33], which was also confirmed in our study. Microbiological test showed that chitooligomers obtained after 


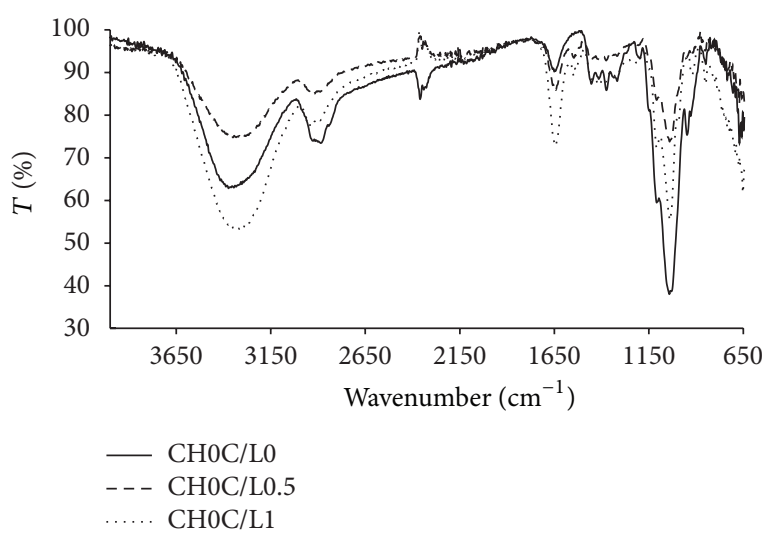

(a)

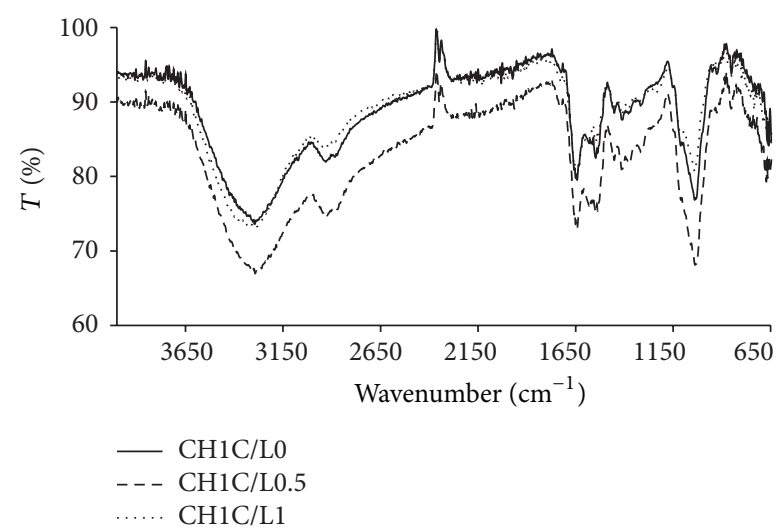

(b)

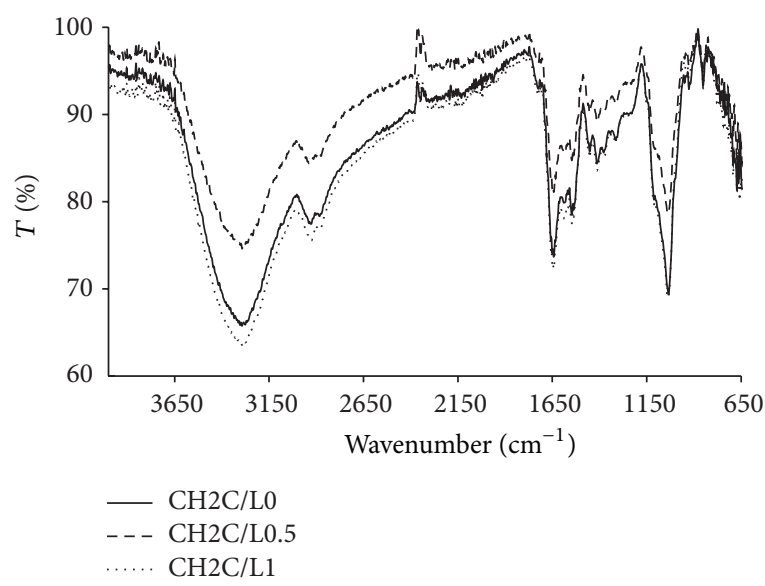

(c)

Figure 3: FTIR spectra of HMPC and C/L preparation films of (a) CH0C/L0, CH0C/L0.5, and CH0C/L1; (b) CH1C/L0, CH1C/L0.5, and $\mathrm{CH} 1 \mathrm{C} / \mathrm{L} 1$; and (c) $\mathrm{CH} 2 \mathrm{C} / \mathrm{L} 0, \mathrm{CH} 2 \mathrm{C} / \mathrm{L} 0.5$, and $\mathrm{CH} 2 \mathrm{C} / \mathrm{L} 1$ variants.

TABLE 3: Antibacterial activity of edible films modified by $\mathrm{CH}$ and $\mathrm{C} / \mathrm{L}$ preparation (main effects).

\begin{tabular}{|c|c|c|c|c|c|}
\hline \multirow{2}{*}{ Main effect } & \multicolumn{5}{|c|}{ Inhibition zone [mm] } \\
\hline & P. fluorescens & E. coli & M. flavus & B. cereus & C. famata \\
\hline \multicolumn{6}{|c|}{ Chitosan [\%] } \\
\hline 0 & $21.9 \pm 1.48^{\mathrm{a}}$ & $22.1 \pm 0.44^{\mathrm{a}}$ & $26.8 \pm 9.34^{\mathrm{a}}$ & $20.0 \pm 0.00^{\mathrm{a}}$ & $22.3 \pm 1.21^{\mathrm{a}}$ \\
\hline 1 & $22.8 \pm 0.60^{\mathrm{b}}$ & $23.1 \pm 0.46^{\mathrm{b}}$ & $31.2 \pm 2.89^{\mathrm{b}}$ & $20.0 \pm 0.00^{\mathrm{a}}$ & $29.5 \pm 1.56^{\mathrm{b}}$ \\
\hline 2 & $24.8 \pm 1.48^{\mathrm{c}}$ & $24.4 \pm 0.89^{c}$ & $33.0 \pm 2.22^{\mathrm{C}}$ & $23.7 \pm 1.27^{\mathrm{b}}$ & $33.0 \pm 1.41^{\mathrm{c}}$ \\
\hline \multicolumn{6}{|c|}{ Cystatin/lysozyme [\%] } \\
\hline 0 & $21.9 \pm 1.46^{\mathrm{a}}$ & $22.7 \pm 0.88^{\mathrm{a}}$ & $26.1 \pm 8.92^{\mathrm{a}}$ & $20.8 \pm 5.65^{\mathrm{a}}$ & $26.9 \pm 4.45^{\mathrm{a}}$ \\
\hline 0.5 & $23.3 \pm 1.70^{\mathrm{b}}$ & $23.0 \pm 1.23^{\mathrm{a}}$ & $32.1 \pm 2.60^{\mathrm{b}}$ & $21.3 \pm 6.94^{\mathrm{b}}$ & $28.4 \pm 4.64^{\mathrm{b}}$ \\
\hline 1 & $24.3 \pm 1.19^{c}$ & $23.8 \pm 1.03^{\mathrm{b}}$ & $32.8 \pm 1.53^{\mathrm{c}}$ & $21.6 \pm 6.50^{\mathrm{b}}$ & $29.6 \pm 5.16^{c}$ \\
\hline
\end{tabular}

Values with different letters $(\mathrm{a}-\mathrm{c})$ within the same column differ significantly $(p<0.05)$.

lysozyme hydrolysis exhibit higher antilisterial activity than chitosan [46]. Interaction effects of statistical analysis showed that inhibition growth of E. coli and P. fluorescens is the result of simultaneous addition of tested bioactive substance. Both species are the food poisoning bacteria in chilled foods. The lack of reduction zone of $B$. cereus growth $(20.0 \mathrm{~mm}$, the same as film diameter) was observed for variants with 0 and $1 \%$ chitosan with $\mathrm{C} / \mathrm{L}$ addition in various concentrations. It confirms what Mellegard et al. have noted that antimicrobial activity of chitosan is concentration-dependent towards $B$. cereus [47]. They have also found out that chitosan with low acetylation degree and higher molecular weight might reduce 
TABLE 4: Antibacterial activity of edible films modified by $\mathrm{CH}$ and $\mathrm{C} / \mathrm{L}$ preparation (interaction effects).

\begin{tabular}{|c|c|c|c|c|c|}
\hline \multirow{2}{*}{ Interaction effects } & \multicolumn{5}{|c|}{ Inhibition zone [mm] } \\
\hline & P. fluorescens & E. coli & M. flavus & B. cereus & C. famata \\
\hline $\mathrm{CH} 0 \mathrm{C} / \mathrm{LO}$ & $20.1 \pm 0.48^{\mathrm{c}}$ & $21.7 \pm 0.11^{c}$ & $20.4 \pm 0.34^{\mathrm{c}}$ & $20.0 \pm 0.00^{\mathrm{a}}$ & $21.2 \pm 0.17^{\mathrm{a}}$ \\
\hline CH0C/L0.5 & $22.2 \pm 0.12^{\mathrm{b}}$ & $22.0 \pm 0.33^{c}$ & $30.4 \pm 0.57^{\mathrm{a}}$ & $20.0 \pm 0.00^{\mathrm{a}}$ & $22.1 \pm 0.72^{\mathrm{a}}$ \\
\hline CH0C/L1 & $23.4 \pm 0.46^{\mathrm{a}}$ & $22.6 \pm 0.09^{\mathrm{b}}$ & $29.7 \pm 0.28^{\mathrm{a}}$ & $20.0 \pm 0.00^{\mathrm{a}}$ & $23.7 \pm 0.58^{\mathrm{e}}$ \\
\hline $\mathrm{CH} 1 \mathrm{C} / \mathrm{L} 0$ & $22.5 \pm 0.70^{\mathrm{ab}}$ & $22.9 \pm 0.51^{\mathrm{ab}}$ & $27.5 \pm 0.19^{\mathrm{d}}$ & $20.0 \pm 0.00^{\mathrm{a}}$ & $28.2 \pm 0.47^{\mathrm{b}}$ \\
\hline CH1C/L0.5 & $22.9 \pm 0.25^{\mathrm{ab}}$ & $22.9 \pm 0.45^{\mathrm{ab}}$ & $32.8 \pm 1.04^{\mathrm{b}}$ & $20.0 \pm 0.00^{\mathrm{a}}$ & $29.4 \pm 1.62^{b}$ \\
\hline $\mathrm{CH} 1 \mathrm{C} / \mathrm{L} 1$ & $23.1 \pm 0.78^{\mathrm{ab}}$ & $23.5 \pm 0.25^{\mathrm{a}}$ & $33.4 \pm 0.99^{\mathrm{b}}$ & $20.0 \pm 0.00^{\mathrm{a}}$ & $30.9 \pm 1.09^{c}$ \\
\hline $\mathrm{CH} 2 \mathrm{C} / \mathrm{L} 0$ & $23.2 \pm 0.28^{\mathrm{c}}$ & $23.5 \pm 0.64^{\mathrm{a}}$ & $30.5 \pm 0.39^{\mathrm{a}}$ & $22.3 \pm 0.70^{\mathrm{b}}$ & $31.2 \pm 0.63^{c}$ \\
\hline $\mathrm{CH} 2 \mathrm{C} / \mathrm{L} 0.5$ & $24.8 \pm 0.21^{\mathrm{d}}$ & $24.2 \pm 0.28^{\mathrm{d}}$ & $33.2 \pm 0.96^{\mathrm{b}}$ & $24.0 \pm 0.70^{\mathrm{c}}$ & $33.7 \pm 0.22^{\mathrm{d}}$ \\
\hline $\mathrm{CH} 2 \mathrm{C} / \mathrm{L} 1$ & $26.5 \pm 0.77^{\mathrm{e}}$ & $25.4 \pm 0.25^{\mathrm{e}}$ & $35.4 \pm 0.66^{\mathrm{e}}$ & $24.9 \pm 0.54^{\mathrm{d}}$ & $34.1 \pm 0.11^{\mathrm{d}}$ \\
\hline
\end{tabular}

Values with different letters (a-e) within the same column differ significantly $(p<0.05)$.

B. cereus growth more effectively than with high acetylation degree and low molecular weight, which also explain very low reduction of these bacteria in our study.

\section{Conclusions}

HPMC films were successfully prepared with chitosan and cystatin/lysozyme preparation. Thermal properties of the HPMC-CH-C/L biocomposites are almost dominated by hydroxypropyl methylcellulose and protein preparation. Hydrolyzed impact of cystatin/lysozyme preparation was observed only in $\alpha$ main chain of HPMC. C/L preparation induces significant changes of tensile strength and elongation at break but has no influence on water vapour permeability. Elongation of films was improved by $\mathrm{CH}$ addition, which is important in coating process of elastic materials, such as raw meat. $\mathrm{C} / \mathrm{L}$ preparation addition results in higher elasticity of obtained biocomposites, because very high $T_{g}$ temperature provides a brittle material. Simultaneous effect of $\mathrm{CH}$ and $\mathrm{C} / \mathrm{L}$ in microbial reduction of every tested microorganism was obtained. Implication of HPMC biocomposites with $\mathrm{CH}$ and bioactive preparation in packaging production system is possible. We also assumed that designed composition is suitable for meat and meat products, due to simplicity of the process to obtain film components and to achieve desired thermomechanical, barrier, and antimicrobial properties.

\section{Conflict of Interests}

The authors declare that there is no conflict of interests regarding the publication of this paper.

\section{Acknowledgment}

This paper is supported by Wroclaw Centre of Biotechnology, programme The Leading National Research Centre (KNOW) for years 2014-2018.

\section{References}

[1] M. Z. Elsabee and E. S. Abdou, "Chitosan based edible films and coatings: a review, Materials Science and Engineering C, vol. 33, no. 4, pp. 1819-1841, 2013.

[2] F. A. Osorio, P. Molina, S. Matiacevich, J. Enrione, and O. Skurtys, "Characteristics of hydroxy propyl methyl cellulose (HPMC) based edible film developed for blueberry coatings," Procedia Food Science, vol. 1, pp. 287-293, 2011.

[3] S. Mathew, M. Brahmakumar, and T. E. Abraham, "Microstructural imaging and characterization of the mechanical, chemical, thermal, and swelling properties of starch-chitosan blend films," Biopolymers, vol. 82, no. 2, pp. 176-187, 2006.

[4] A. Hambleton, M.-J. Fabra, F. Debeaufort, C. Dury-Brun, and A. Voilley, "Interface and aroma barrier properties of iotacarrageenan emulsion-based films used for encapsulation of active food compounds," Journal of Food Engineering, vol. 93, no. 1, pp. 80-88, 2009.

[5] J. Gómez-Estaca, L. Bravo, M. C. Gómez-Guillén, A. Alemán, and P. Montero, "Antioxidant properties of tuna-skin and bovine-hide gelatin films induced by the addition of oregano and rosemary extracts," Food Chemistry, vol. 112, no. 1, pp. 18$25,2009$.

[6] S. D. Figueiró, J. C. Góes, R. A. Moreira, and A. S. B. Sombra, "On the physico-chemical and dielectric properties of glutaraldehyde crosslinked galactomannan-collagen films," Carbohydrate Polymers, vol. 56, no. 3, pp. 313-320, 2004.

[7] G. Y. Park, S. Mun, Y. Park et al., "Influence of encapsulation of emulsified lipids with chitosan on their in vivo digestibility," Food Chemistry, vol. 104, no. 2, pp. 761-767, 2007.

[8] R. Porta, L. Mariniello, P. di Pierro, A. Sorrentino, and C. V. L. Giosafatto, "Transglutaminase crosslinked pectin- and chitosan-based edible films: a review," Critical Reviews in Food Science and Nutrition, vol. 51, no. 3, pp. 223-238, 2011.

[9] S. Rawdkuen, P. Suthiluk, D. Kamhangwong, and S. Benjakul, "Mechanical, physico-chemical, and antimicrobial properties of gelatin-based film incorporated with catechin-lysozyme," Chemistry Central Journal, vol. 6, article 131, 2012.

[10] A. Zimoch-Korzycka, J. Ambrozik-Haba, D. Kulig, and A. Jarmoluk, "Modification effect of cellulase on the physicochemical characteristic of polysaccharides edible films," International 
Journal of Polymer Science, vol. 2015, Article ID 184616, 7 pages, 2015.

[11] S. Kamel, N. Ali, K. Jahangir, S. M. Shah, and A. A. El-Gendy, "Pharmaceutical significance of cellulose: a review," eXPRESS Polymer Letters, vol. 2, no. 11, pp. 758-778, 2008.

[12] M. M. Al-Tabakha, "HPMC capsules: current status and future prospects," Journal of Pharmacy and Pharmaceutical Sciences, vol. 13, no. 3, pp. 428-442, 2010.

[13] S. Jain, P. S. Sandhu, R. Malvi, and B. Gupta, "Cellulose derivatives as thermoresponsive polymer: an overview," Journal of Applied Pharmaceutical Science, vol. 3, no. 12, pp. 139-144, 2013.

[14] M. J. Akhtar, M. Jacquot, E. Arab-Tehrany, C. Gaïani, M. Linder, and S. Desobry, "Control of salmon oil photo-oxidation during storage in HPMC packaging film: influence of film colour," Food Chemistry, vol. 120, no. 2, pp. 395-401, 2010.

[15] Y.-B. Wu, S.-H. Yu, F.-L. Mi et al., "Preparation and characterization on mechanical and antibacterial properties of chitsoan/cellulose blends," Carbohydrate Polymers, vol. 57, no. 4, pp. 435-440, 2004.

[16] T. Wu, S. Zivanovic, F. A. Draughon, W. S. Conway, and C. E. Sams, "Physicochemical properties and bioactivity of fungal chitin and chitosan," Journal of Agricultural and Food Chemistry, vol. 53, no. 10, pp. 3888-3894, 2005.

[17] C. Valenzuela, L. Abugoch, and C. Tapia, "Quinoa proteinchitosan-sunflower oil edible film: mechanical, barrier and structural properties," LWT: Food Science and Technology, vol. 50, no. 2, pp. 531-537, 2013.

[18] J. Rhoades and S. Roller, "Antimicrobial actions of degraded and native chitosan against spoilage organisms in laboratory media and foods," Applied and Environmental Microbiology, vol. 66, no. 1, pp. 80-86, 2000.

[19] G. G. Buonocore, A. Conte, M. R. Corbo, M. Sinigaglia, and M. A. Del Nobile, "Mono- and multilayer active films containing lysozyme as antimicrobial agent," Innovative Food Science \& Emerging Technologies, vol. 6, no. 4, pp. 459-464, 2005.

[20] A. Conte, G. G. Buonocore, M. Sinigaglia, and M. A. Nobile, "Development of immobilized lysozyme based active film," Journal of Food Engineering, vol. 78, no. 3, pp. 741-745, 2007.

[21] E. D. N. S. Abeyrathne, H. Y. Lee, and D. U. Ahn, "Egg white proteins and their potential use in food processing or as nutraceutical and pharmaceutical agents-a review," Poultry Science, vol. 92, no. 12, pp. 3292-3299, 2013.

[22] W. Kopec and T. Trziszka, "Lysozyme and its characteristics. Part II. Isolation and practical applications," Food Industry, vol. 3, pp. 36-37, 1997 (Polish).

[23] Y. M. C. Henskens, E. C. L. Veerman, and A. V. N. Amerongen, "Cystatins in health and disease," Biological Chemistry HoppeSeyler, vol. 377, no. 2, pp. 71-86, 1996.

[24] E. Wesierska, Y. Saleh, T. Trziszka, W. Kopec, M. Siewinski, and K. Korzekwa, "Antimicrobial activity of chicken egg white cystatin," World Journal of Microbiology and Biotechnology, vol. 21, no. 1, pp. 59-64, 2005.

[25] A. Kolaczkowska, M. Kolaczkowski, A. Sokolowska et al., "The antifungal properties of chicken egg cystatin against Candida yeast isolates showing different levels of azole resistance," Mycoses, vol. 53, no. 4, pp. 314-320, 2010.

[26] A. R. Collins and A. Grubb, "Cystatin D, a natural salivary cysteine protease inhibitor, inhibits coronavirus replication at its physiologic concentration," Oral Microbiology \& Immunology, vol. 13, no. 1, pp. 59-61, 1998.
[27] T. Skiba, W. Kopeć, and $Ł$. Bobak, "Chemo-thermal method of initial isolation of bioactive proteins from egg white," Przemysl Chemiczny, vol. 91, no. 4, pp. 527-530, 2012 (Polish).

[28] G. Lesnierowski and J. Kijowski, "Lysozyme," in Bioactive Egg Compounds, R. Huopalahti, R. Lopez-Fandino, M. Anton, and R. Schade, Eds., pp. 35-37, Springer, Berlin, Germany, 2007.

[29] M. Siewiński, "Method of purification of thiol proteinase inhibitors from human urine," Cancer Biochemistry Biophysics, vol. 12, no. 1, pp. 33-43, 1991.

[30] M. A. Daeschel, T. Musafija-Jeknic, Y. Wu, D. Bizzarri, and A. Villa, "High-performance liquid chromatography analysis of lysozyme in wine," American Journal of Enology and Viticulture, vol. 53, no. 2, pp. 154-157, 2002.

[31] ASTM, "Standard test methods for water vapor transmission of materials," ASTM E96/E96M-13, ASTM International, West Conshohocken, Pa, USA, 2013.

[32] M. Y. Arancibia, A. Alemán, M. E. López-Caballero, M. C. Gómez-Guillén, and P. Montero, "Development of active films of chitosan isolated by mild extraction with added protein concentrate from shrimp waste," Food Hydrocolloids, vol. 43, pp. 91-99, 2015.

[33] R. J. Nordtveit, K. M. Vårum, and O. Smidsrød, "Degradation of partially $\mathrm{N}$-acetylated chitosans with hen egg white and human lysozyme," Carbohydrate Polymers, vol. 29, no. 2, pp. 163-167, 1996.

[34] S.-I. Park, M. A. Daeschel, and Y. Zhao, "Functional properties of antimicrobial lysozyme-chitosan composite films," Journal of Food Science, vol. 69, no. 8, pp. M215-M221, 2004.

[35] M. H. Hosseini, S. H. Razavi, and M. A. Mousavi, "Antimicrobial, physical and mechanical properties of chitosan-based films incorporated with thyme, clove and cinnamon essential oils," Journal of Food Processing and Preservation, vol. 33, no. 6, pp. 727-743, 2009.

[36] M. Imran, S. El-Fahmy, A.-M. Revol-Junelles, and S. Desobry, "Cellulose derivative based active coatings: effects of nisin and plasticizer on physico-chemical and antimicrobial properties of hydroxypropyl methylcellulose films," Carbohydrate Polymers, vol. 81, no. 2, pp. 219-225, 2010.

[37] M. N. V. R. Kumar, R. A. A. Muzzarelli, C. Muzzarelli, H. Sashiwa, and A. J. Domb, "Chitosan chemistry and pharmaceutical perspectives," Chemical Reviews, vol. 104, no. 12, pp. 60176084, 2004.

[38] A. Hashemi Doulabi, H. Mirzadeh, and M. Imani, "Interaction and miscibility study of fumarate-based macromers with chitosan," Materials Chemistry and Physics, vol. 139, no. 2-3, pp. 515-524, 2013.

[39] M. Mucha and A. Pawlak, "Thermal analysis of chitosan and its blends," Thermochimica Acta, vol. 427, no. 1-2, pp. 69-76, 2005.

[40] R. E. Wetton, "Dynamic mechanical thermal analysis of polymers and related systems," in Developments in Polymer Characterization, J. V. Dawkins, Ed., pp. 179-222, Springer, New York, NY, USA, 1986.

[41] Y. Wan, H. Wu, A. Yu, and D. Wen, "Biodegradable polylactide/chitosan blend. Membranes," Biomacromolecules, vol. 7, no. 4, pp. 1362-1372, 2006.

[42] C. Gustafsson, C. Nyström, H. Lennholm, M. C. Bonferoni, and C. M. Caramella, "Characteristics of hydroxypropyl methylcellulose influencing compactibility and prediction of particle and tablet properties by infrared spectroscopy," Journal of Pharmaceutical Sciences, vol. 92, no. 3, pp. 494-504, 2003. 
[43] R. K. Wanchoo and P. K. Sharma, "Viscometric study on the compatibility of some water-soluble polymer-polymer mixtures," European Polymer Journal, vol. 39, no. 7, pp. 1481-1490, 2003.

[44] M. I. Lopes, J. T. Martins, L. P. Fonseca, and A. A. Vicente, "Effect of glucose oxidase incorporation in chitosan edible films properties," in Proceedings of the 6th International CIGR Symposium on Towards a Sustainable Food Chain: Food Process, Bioprocessing and Food Quality Management, Nantes, France, April 2011.

[45] K.-M. Wang, S. Kumar, Y.-S. Cheng, S. Venkatagiri, A.-H. Yang, and K.-W. Yeh, "Characterization of inhibitory mechanism and antifungal activity between group-1 and group-2 phytocystatins from taro (Colocasia esculenta)," The FEBS Journal, vol. 275, no. 20, pp. 4980-4989, 2008.

[46] A. Zimoch-Korzycka, C. Gardrat, A. Castellan, V. Coma, and A. Jarmoluk, "The use of lysozyme to prepare biologically active chitooligomers," Polímeros, vol. 25, no. 1, pp. 35-41, 2015.

[47] H. Mellegård, C. From, B. E. Christensen, and P. E. Granum, "Inhibition of Bacillus cereus spore outgrowth and multiplication by chitosan," International Journal of Food Microbiology, vol. 149, no. 3, pp. 218-225, 2011. 

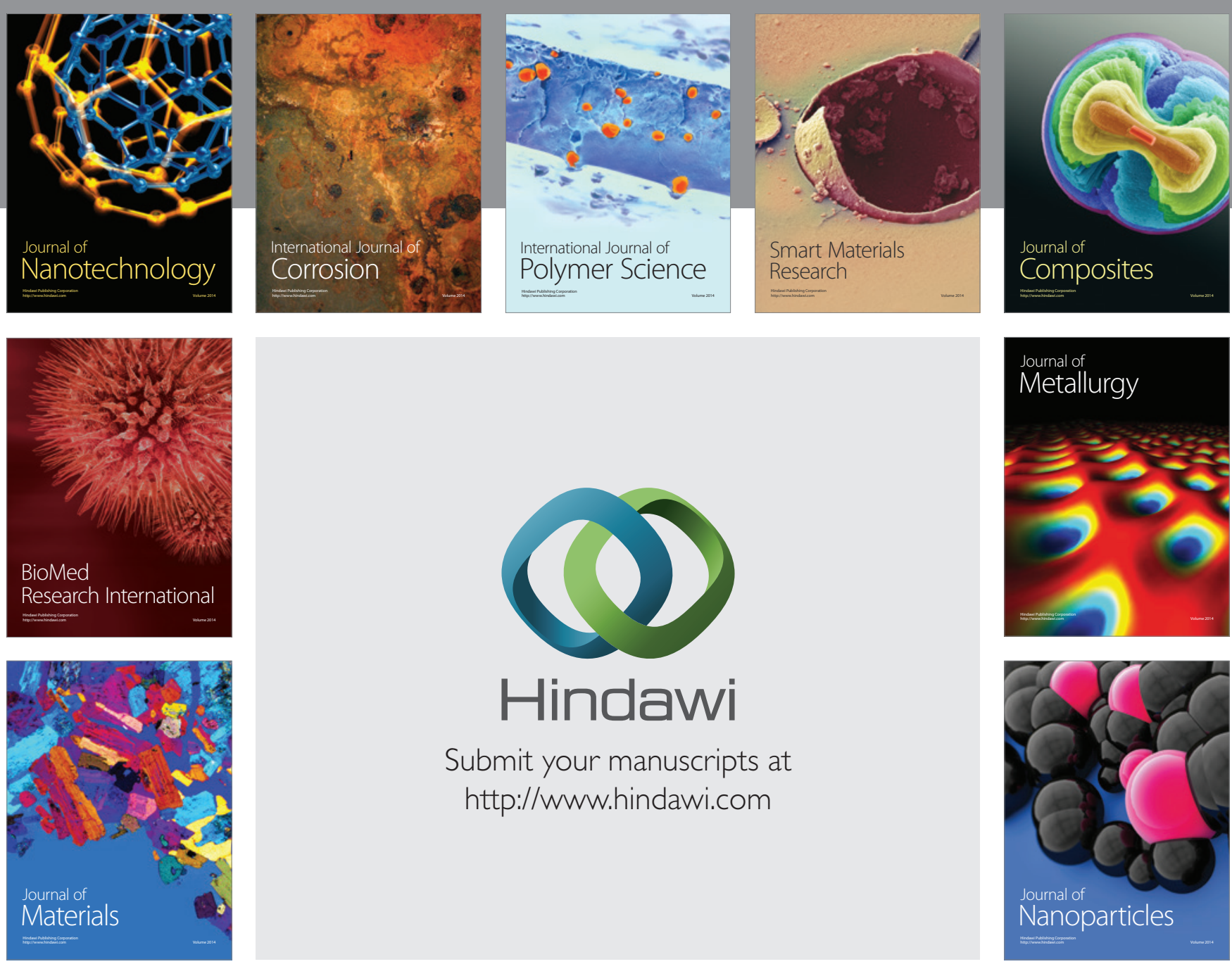

Submit your manuscripts at http://www.hindawi.com
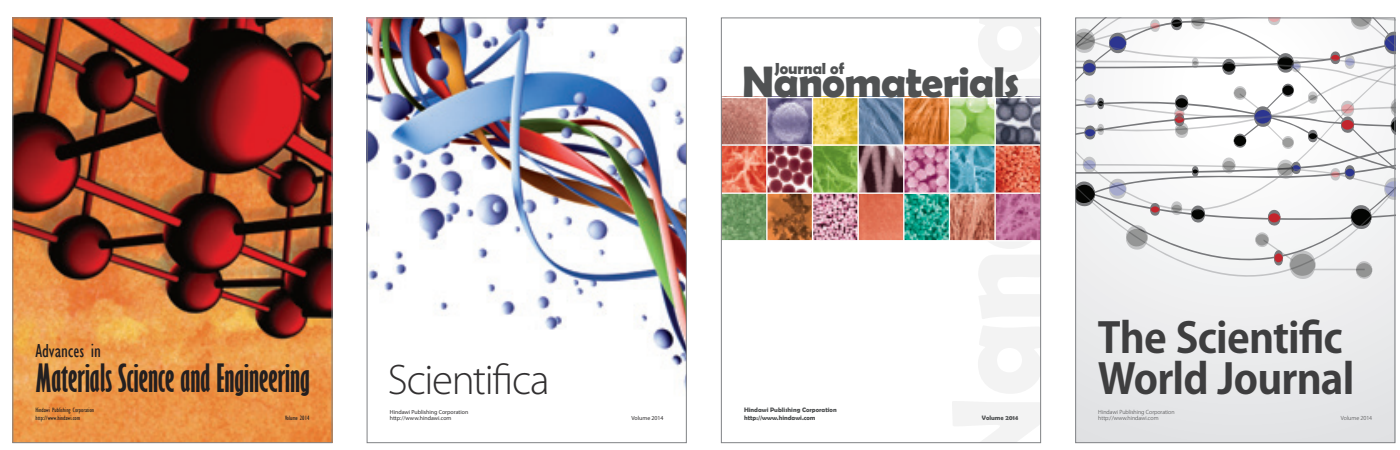

\section{The Scientific World Journal}
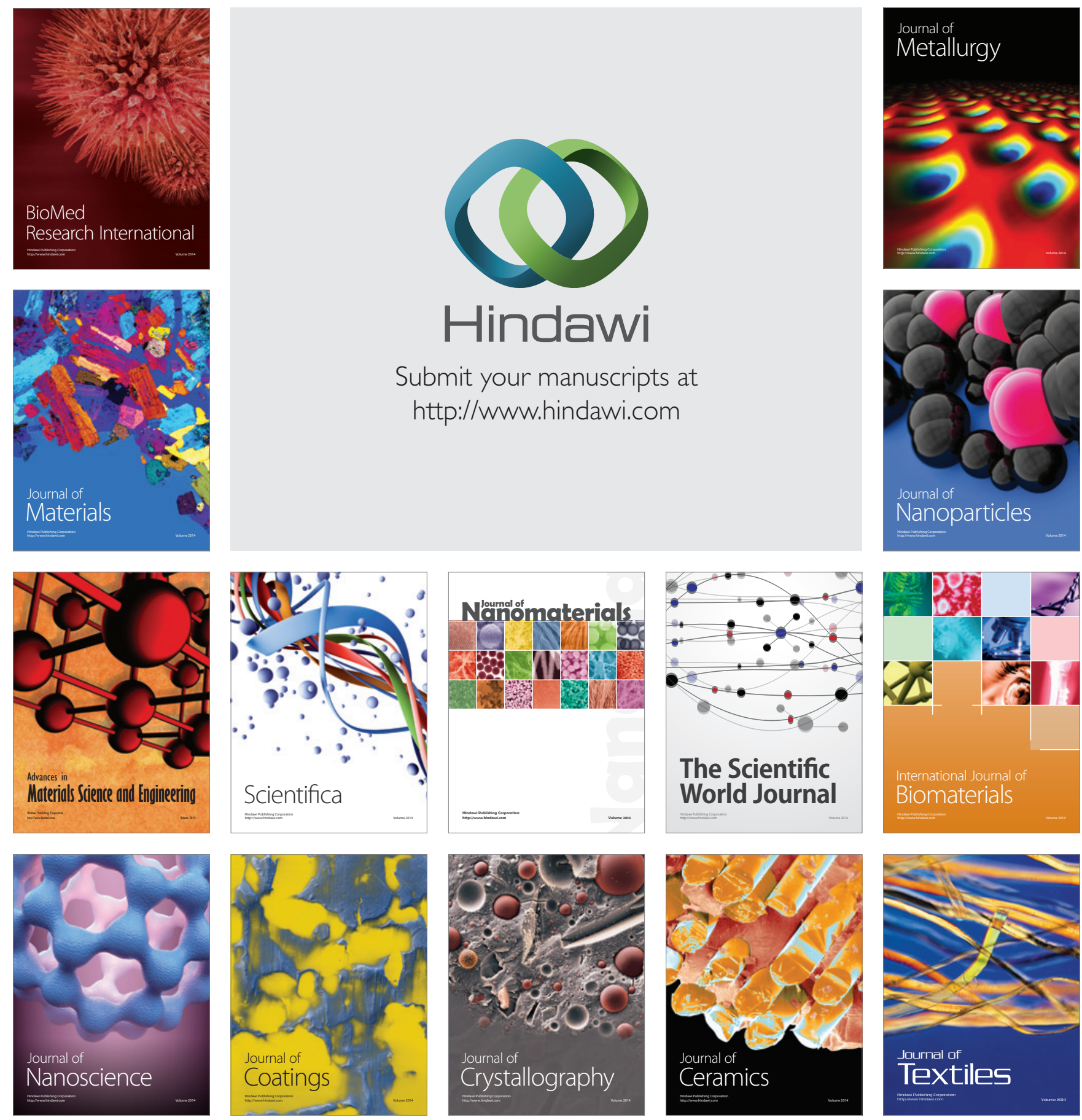